\title{
A Computer Simulation of Unsteady-State Gas Flow in Pipe Line
}

\author{
Tatsuo TANAKA*
}

\begin{abstract}
A simulator for unsteady state gas flow in pipe lines was made in the computer. The gas flow was indicated by the Kinetic Formula and the Continuity Equation. The Simultaneous Difference Equations of these equations were used in the simulator, and the simulations were conducted to find the best simulation approach. The final simulation selected matched the field performance satisfactorily.
\end{abstract}

\section{Introduction}

When the pressure or the flow rate of a gas, which is flowing in a steady state in a gas pipe line, is altered by some disturbance at the end of the line, the flow is changed to an unsteady state, and the disturbance is transmited through the line with time. A theoretical analysis of the above problem is carried out in this paper. An unsteady-state gas flow in a pipeline can be indicated by the Kinetic Formula and the Continuity Equation. These equations were developed in to the 'Simultaneous Difference Equations', and a simulator was made in the computer.

Several simulations were conducted to find the best approach to simulation and to reliability of the simulator. The final simulation results compared well with the field data as shown in Fig. 10. Later, the author has succeeded in the automatic computer control of the Nakajo Gas Field by applying this simulation model.1)

\section{Gas Flow Equation}

There are many equations ${ }^{2) \sim 4}$ ) which express the phenomena of unsteady state gas flow in a pipeline. However, the most suitable equations may be the Kinetic Formula and the Continuity Equation.

\subsection{Kinetic Formula}

If it is assumed that (1) the pipeline is horizontal, (2) the cross section area is constant, (3) the body force can be neglected, and (4) heat change is isothermal, the Kinetic Formula is derived as follows: ${ }^{5)}$

$$
\frac{\partial(\rho V)}{\partial t}+V \frac{\partial(\rho V)}{\partial x}+\frac{\partial P}{\partial x} g
$$

Received Jan. 20, 1982.

* Nippon Mining Co. Ltd., (10-1, Toranomon 2-Chome, Minato-ku, Tokyo 105)

$$
=-\frac{1}{2} f_{m} \rho V^{2} \pi D / S
$$

\subsection{Continuity Equation}

If the flow in the pipeline is one dimensional ( $x$ axis) and the cross section area $(S)$ is constant, the Continuity Equation in infinitesimal volume can be shown as follows:

$$
\frac{\partial \rho}{\partial t}+\frac{\partial(\rho V)}{\partial x}=0
$$

\section{Difference Equations}

Eqs. (1) and (2) in common field units are shown as follows:

$$
\begin{aligned}
& \frac{\partial Q_{n}}{\partial t}+\frac{P_{0}}{P} \frac{T}{T_{0}}-\frac{Z}{Z_{0}} \frac{Q_{n}}{S} \frac{\partial Q_{n}}{\partial x} \\
& \quad+\left(\frac{R T_{0} Z_{0} S g}{M G P_{0}}\right) \frac{\partial P}{\partial x}=-\frac{f_{m} P_{0} T Z \pi D}{2 P T_{0} Z_{0} S^{2}} Q_{n}{ }^{2} \\
& \frac{\partial Q_{n}}{\partial x}+\frac{T_{0} Z_{0} S}{P_{0} T Z} \frac{\partial P}{\partial t}=0
\end{aligned}
$$

Then the 'Simultaneous Difference Equations' can be obtained as follows :

$$
\begin{aligned}
& Q_{n}(x, t+\Delta t)=Q_{n}(x, t) \\
& +\Delta t\left[-2.679 \frac{f_{m} \bar{Z}}{Z_{0}} \frac{\bar{T} Q_{n}{ }^{2}(x, t)}{D^{3} P(x, t)}-1.339\right. \\
& \times 10^{-5} \frac{\bar{Z}}{Z_{0} D^{2}} \frac{\bar{T} Q_{n}(x, t)}{P(x, t)} \frac{Q_{n}(x+\Delta x, t)-Q_{n}(x-\Delta x, t)}{2 \Delta x} \\
& \left.-21.44 \frac{Z_{0} D^{2}}{G} \frac{P(x+\Delta x, t)-P(x-\Delta x, t)}{2 \Delta x}\right] \\
& P(x, t+\Delta t)=P(x, t)-1.339 \times 10^{-5} \frac{\overline{Z T}}{Z_{0} D^{2}} \frac{\Delta t}{2 \Delta x} \\
& {\left[Q_{n}(x+\Delta x, t)-Q_{n}(x-\Delta x, t)\right]}
\end{aligned}
$$

The coefficients of the equations are calculated with the following constant values :

$P_{0}=1.034 \mathrm{Kg} / \mathrm{cm}^{2} \cdot$ abs.

$T_{0}=273.2 \mathrm{~K}$

$R=847.8 \mathrm{Kg}-\mathrm{m} / \mathrm{kg}-\mathrm{mol} \cdot \mathrm{K}$

$M=28.97 \mathrm{~kg} / \mathrm{kg}-\mathrm{mol}$

$g=9.807 \mathrm{~m} / \mathrm{sec}^{2}$

The unit of flow rate, $\left(Q_{n}\right)$, is $\mathrm{m}^{3} / \mathrm{hr}$ and that 


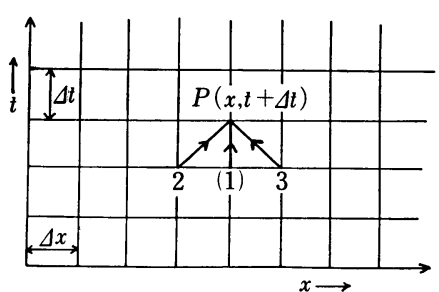

$P$ Plane

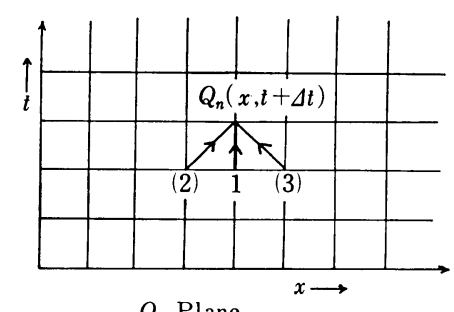

$Q_{n}$ Plane

$Q_{n}(x, t+\Delta t)$ will be calculated by using all six values. : Eq. (8) $P(x, t+\Delta t)$ will be calculated by using bracketed three values. : Eq. (9)

Fig. 1 The Calculation Steps

of the pipeline length, $(x)$, is $\mathrm{km}$. The others are the same as those shown in the list of nomenclature. The calculation steps of the Difference Equations (Eqs. (5) and (6)) are illustrated in Fig. 1. Therefore, these simultaneous difference equations may need the following values for initial and boundary conditions.

Initial Conditions : $\quad Q_{n}(x, 0) ; P(x, 0)$

Boundary Conditions : $Q_{n}(0, t) ; P(0, t)$

$$
Q_{n}(L, t) ; P(L, t)
$$

\section{Steady-State Gas Flow Equation}

In the steady state, Eq. (3) becomes as follows :

$$
\frac{d P}{d x}=\frac{28.97 G}{R g}\left(\frac{P_{0}}{T_{0}} \frac{1}{Z_{0}} \frac{1}{S}\right)^{2} \frac{f_{m} \bar{Z} D \bar{T} \pi}{2 S P} Q_{n}{ }^{2}
$$

The Difference Equation of the above equation is therefore developed as follows :

$$
P(x \pm \Delta x)=P(x) \mp 0.1248 \frac{G f_{m} \bar{Z} \bar{T}}{D^{5} Z_{0}^{2} P(x)} Q_{n}^{2}(x) \Delta x
$$

$$
Q_{n}(x)=\sqrt{\left|[P(x)-P(x+\Delta x)] \frac{D^{5} Z_{0}^{2} P(x)}{0.1248 G f_{m} \bar{Z} \bar{T}}\right|}
$$

The coefficients and units of the equation are calculated with the same values as in Eqs. (5) and (6).

\section{The Simulator}

The similator is constructed by Eqs. (5) and (6), and it is started by generating the pressure or flow rate change at either end of the pipeline in which the gas is flowing in a steady state. This disturbance is assumed, for simplifying the problem, to be maintained throughout the simulation time. The other conditions of simulator are as follows.

\subsection{Initial and Boundary Values}

At the start of simulation, the flow is assumed to be in a steady state. The initial values $\left(Q_{n}\right.$ $(x, 0) \& P(x, 0))$ therefore, are defined in the following equation, which is obtained from Eq.

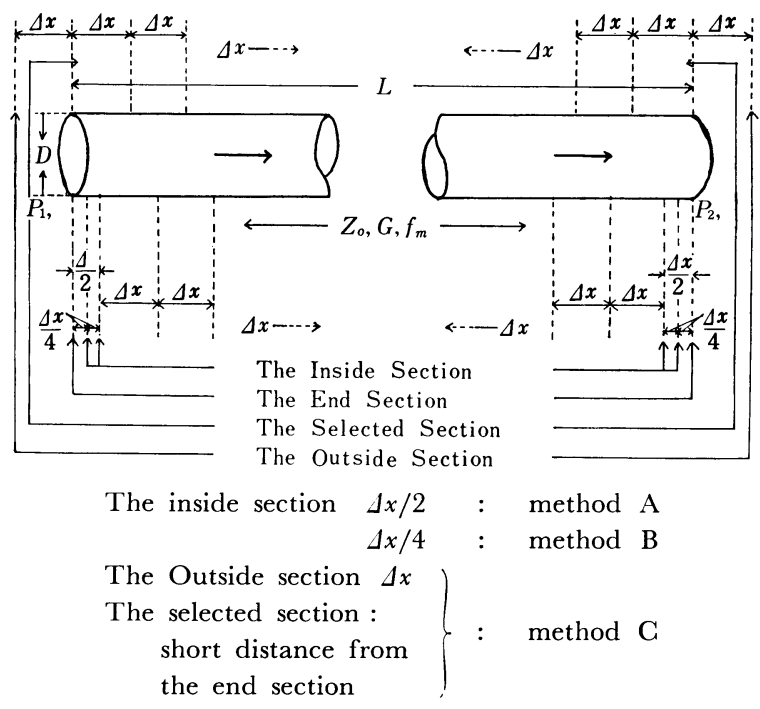

Fig. 2 The Difinition of Terms in This Simulation

(7).

$$
P_{1}^{2}-P_{2}^{2}=0.2497 \frac{G f_{m} \bar{Z} \bar{T} L}{Z_{0}^{2} D^{5}} Q_{n}^{2}
$$

The boundary values require four values, two of which can be determined by the value of generated disturbance or the initial condition, because of the assumption that the disturbance is maintained throughout the simulation time. However, the other two boundary values cannot be determined, because these values are the very answers which must be obtained by this simulation. If the section is spaced out at a very small distance from either end section of the pipeline, the gas flow between that section and the end section can be assumed immediately to be in a steady state. (Hereafter, this section is called 'the inside section'.) Hence these two boundary values (the values of the end sections) may be calculated by means of the steady state flow equations (Eqs. (8) and (9)) using the value of the inside section which can be calculated by this simulator. The whole pipeline length, therefore, is divided into several equal spans $(\Delta x)$, and the inside section is 
selected with half length or quarter length of the span $(\Delta x / 2, \Delta x / 4)$ from the end section as shown in Fig. 2. (Hereafter, these are called methods A and B.) When the whole pipeline is very long, the inside section cannot be selected at a short distance from the end sections in methods A and B. Therefore, the flow between the end section and the inside section in this case cannot be assumed immediately to be in a steady state. Then another method is defined as follows: an image section, whose distance is $\Delta x$ to outside of pipeline from the end section, is made (see Fig. 2) and the flow condition between this image section and the end section is assumed to be in a steady state at any time. (Hereafter this image section is called 'the outside section') The order of calculation is, therefore, defined as follows in this method. (called method G).

(1) Select a section inside the pipeline where the state of flow between this section and the end section could become steady immediately. (see Fig. 2 : Hereafter this section is called 'the selected section') The distance between the selected section and the end section therefore depends on the value of disturbance and of calculation step $\Delta t$ at simulation.

(2) Calculate the initial condition of each of the $x_{\mathrm{i}}$ sections and the selected section and the outside section.

(3) Calculate the flow rate or pressure at the end section at disturbance-generated time $(\Delta t=$ 0 ). If the disturbance is pressure (flow rate), the flow rate (pressure) at the end section at disturbance generated is unknown, then calculate this value by using the initial pressure at the selected section and the disturbance pressure (flow rate) at the end section, by steady state flow equation (Eq. (10)).

(4) Calculate the pressure at the outside section by Eq. (10). [The flow rate at the outside section is the same as at the end section, because of the flow between the outside section and the end section is assumed to be in a steady state.

(5) Calculate the flow rate and pressure at each section at step $\Delta t$ by Eqs. (5) and (6).

(6) Continue to calculate in the same way for step (4) and (5).

\subsection{Selection of Calculation Span ' $r$ '}

Generally, the value of ' $r$ ' $(\Delta t / \Delta x)$, which is smaller than the reciprocal of velocity in the pipeline, is acceptable to the differential equations such as Eqs. (5) and (6). However, if this value is selected to be smaller, the computing time will be longer. Therefore, several values are selected in the case analysis for finding the largest value of ' $r$ '

\subsection{Procedure of Simulation}

By considering the gas flow, it may be noted that if no pressure change appeares around certain points $\left(x_{k}\right)$ in the pipeline during a short specific time $(\Delta t)$, the flow rate at that point will not change. However, in the case of simulation by using Eq. (5), even when there is no pressure change in the points $\left(x_{k}-\Delta x, x_{k}, x_{k}+\Delta x\right)$ during the short time, $\Delta t$, the flow rate $Q_{n}\left(x_{k}, t+\Delta t\right)$ may not be exactly the same value as the flow rate $Q_{n}\left(x_{k}, t\right)$, which was derived previously, because of the round-off error in Eqs. (5) and (6). On the other hand, in this simulator, the roundoff error may appear greater in the flow rate than in the pressure at each step, as specified in Fig. $\mathbf{1}$ and Eqs. (5) and (6). The following procedure, therefore, was developed. When the simulator is started, at first, the pressure of each section along the pipeline $\left(P\left(x_{i}, t+\Delta t\right)\right.$ is calculated, and if the pressure change at any three points, $\left(x_{k},-\Delta x, x_{k}\right.$, $\left.x_{k}+\Delta x\right)$, is smaller than $\varepsilon$ compare with the pressure of the previous calculation, (the pressure which is derived at time $t$ ) Eq. (5) should not be used and it, $\left(Q_{n}\left(x_{k}, t+\Delta t\right)\right)$, should be fixed at the same rate as previous rate, $Q_{n}\left(x_{k}, t\right)$. Only in the case of pressure change appearing larger than $\varepsilon$ at one of these three points, Eq. (5) can be used for calculating the flow rate at the second step $(t+\Delta t)$ such as $Q_{n}\left(x_{k}, t+\Delta t\right)$. The several values of $\varepsilon$ are selected in the next section for finding the best value.

\section{Case Analysis and Results}

Two kinds of analyses were carried out for seeking the best simulation approach and for exploring the reliability of the simulator. In both analyses, the pipeline data used were the actual pipeline data which are being used in NAKAJO GAS FIELD. Namely;

(1) The diameter of the flow line is $30.47 \mathrm{~cm}$ (12 inches) and its length is $6.645 \mathrm{~km}$.

(2) Friction coefficient $\left(f_{m}\right)$ is 0.003155 , which was calculated from Eq. (10) using the actual data of the above pipeline. (If Weymouth Equation ${ }^{4}$ ) is used, $f_{m}$ may be calculated to be 0.003477 .

\subsection{Case Analysis A}

The purpose of the first analysis is to find out the best simulation approach. Several case analyses therefore were carried out for each objective. 
Any simulation is assumed to be generated by pressure disturbance at the outlet point, down stream, and this disturbance pressure was maintained throughout the simulation time. The following conditions, therefore, were used in this case analysis.

(1) Initial condition; It should be selected from the actual data of the same pipeline when the flow is in a steady state. Therefore :

$$
\begin{aligned}
& Q_{n}: 35,325 \mathrm{~m}^{3} / \mathrm{hr} \\
& P_{1}: 8.93 \mathrm{Kg} / \mathrm{cm}^{2} \\
& P_{2}: 5.51 \mathrm{Kg} / \mathrm{cm}^{2} \\
& \bar{T}: 29.35^{\circ} \mathrm{G} \\
& Z_{0}: 0.98 \\
& G: 0.65
\end{aligned}
$$

(2) The boundary condition : The disturbance is generated one time at outlet pressure $(5.51 \rightarrow 5.20)$ and this value is maintained. Therefore;

* The pressure at the inlet point is kept at initial pressure $8.93 \mathrm{Kg} / \mathrm{cm}^{2}$.

* The pressure at the outlet point is kept at disturbance pressure $5.20 \mathrm{Kg} / \mathrm{cm}^{2}$.
* The flow rate at both end sections are calculated by using methods A,B or $\mathrm{C}$.

\subsubsection{The Calculation Span ' $r$ '}

Eight case analyses were carried out for finding the most suitable value of ' $r$ ' $(\Delta t / \Delta x)$. In all of the eight case analyses, the simulation conditions were as follows.

(1) Calculation method for boundary values : method A. (the inside section is $\Delta x / 2$ )

(2) The value of $\varepsilon: 1 \times 10^{-5}$.

The results of simulations are shown in Table 1. Column 4 indicates $2(\Delta t / \Delta x)$ instead of $\Delta t / \Delta x$, because method $\mathrm{A}$ was used.

\subsubsection{The Calculation of Boundary Condition}

Three case analyses were carried out for considering a suitable method to determine the boundary values. The value of $\varepsilon$ used was $1 \times 10^{-5}$ in all case analyses. The results of simulation are shown in Table 2.

\subsubsection{The Value of $\varepsilon$}

Four case analyses were carried out for studying the most suitable value of $\varepsilon$. The simulation conditions were as follows :

Table 1 Comparison of Simulation Results —Changing ' $r$ ' -

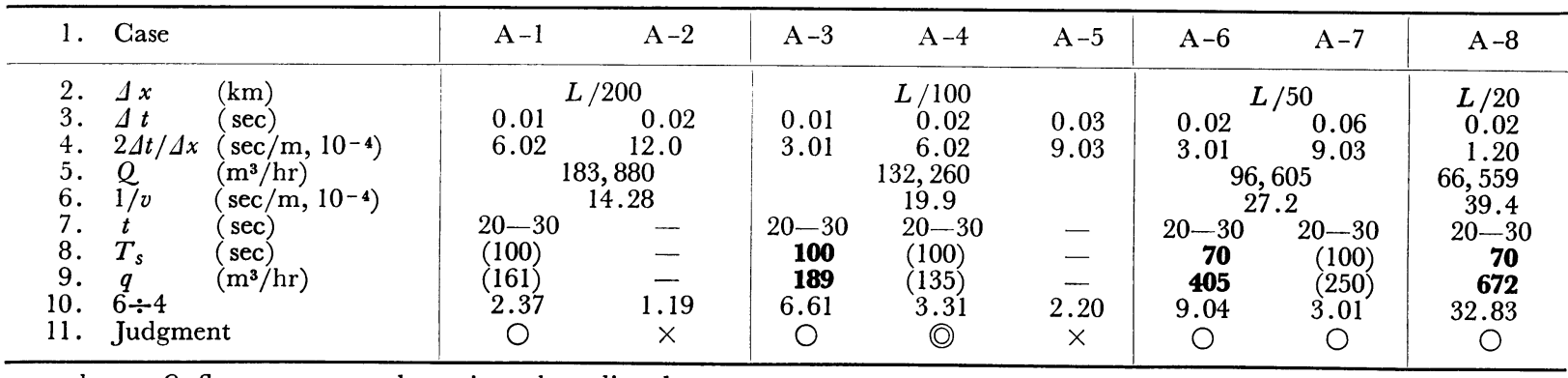

where; $Q$ flow rate at outlet point when disturbance generate

$v$ velocity

$t$ time, when inlet flow rate is changed

$T_{s}$ stabilized time.

Gothic figures; the time when both flow rate, inlet and outlet point were getting constant

( ) ; the time when both flow rate are still changing but changing rate is very small

$q$ flow rate difference between inlet and outlet point at $T_{s}$

- illogical value

Judgment () better $\bigcirc:$ good $\times$ : bad

(consideration by $t, T_{s}$ and $q$ )

Table 2 Comparison of Simulation Results_- Ghanging Calculation Method of Boundary Condition-

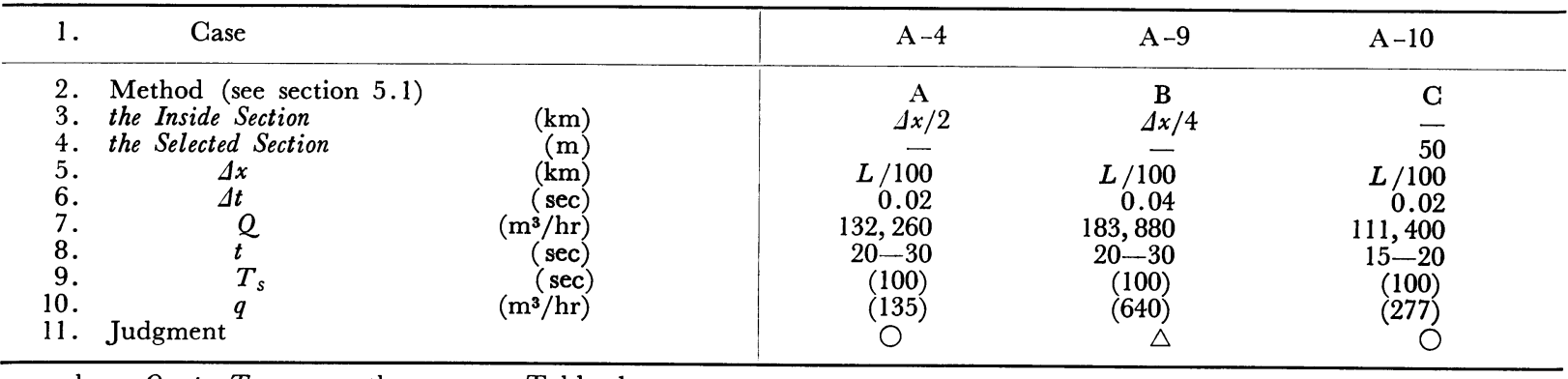

where $Q, t, T s, q$ are the same as Table 1 
(1) The calculation method of boundary values : method $\mathrm{G}$

(2) The selected section : 50 meters from the end section.

(3) $\Delta x: L / 30 \quad$ (4) $\Delta t: 0.05 \mathrm{sec}$.

The results of four case analyses are as shown

\section{in Table 3.}

\subsubsection{The Selected Section}

Four case analyses were carried out for finding a suitable distance of the selected section in method C. The value of $\varepsilon$ used is $1 \times 10^{-5}$ in these analyses.

The results of simulation are shown in Table 4. It is noted that A-18 is the best simulation way in the eighteen case analyses. The reasons are described in the discussion given in section 7. The simulation method in A-18 is, therefore, selected in the case analysis $\mathrm{B}$ in section 6.2.
The result of flow phenomenon in A-18 is also shown in Fig. 3 to Fig. 8. Fig. 3 to 6 indicate the change of pressure and flow rate around the outlet point and the inlet point since the disturbance was generated. Figs. 7 and $\mathbf{8}$ indicate the same phenomenon as Fig. 3 to 6 but along the whole length of the line.

\subsection{Case Analysis B}

The purpose of second analysis is for exploring the reliability of the simulator. Therefore, the actual phenomena of flow rate change at inlet and outlet points are used as generated disturbance and simulated the pressure change at both end sections. Then the results obtained were compared with the real pressure changes. In the analysis, therefore, the following conditions and data were used which were selected from the same pipeline as described in analysis A.

Table 3 Comparison of Simulation Results_-Changing Value of $\varepsilon$

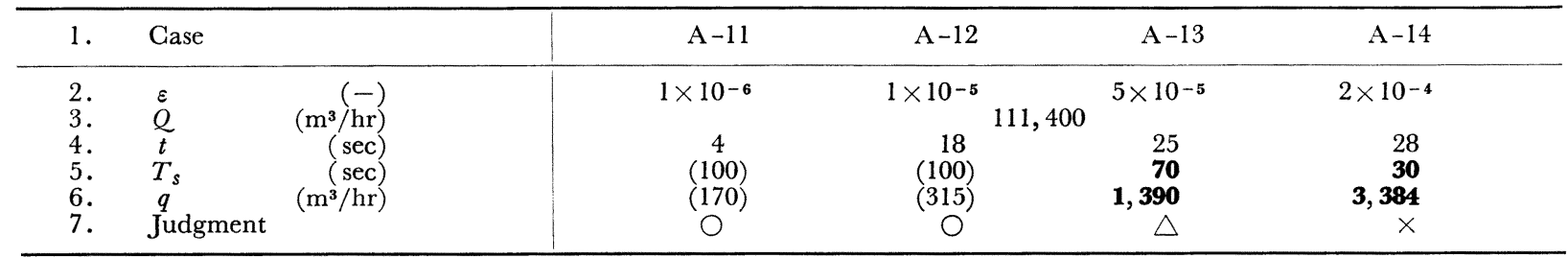

where $Q, t, T_{s}, q$ are the same as Table 1

Table 4 Comparison of Simulation Results - Changing the Selected Section-

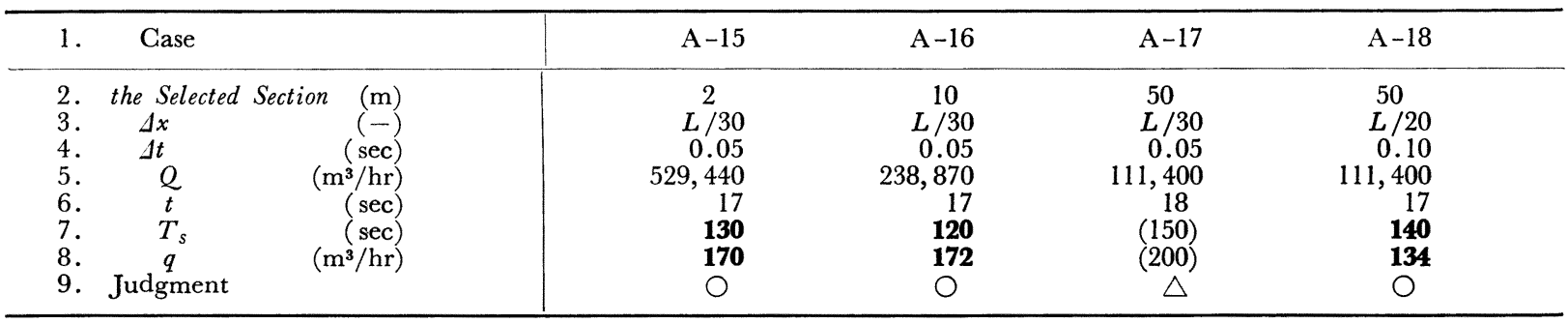

where $Q, t, T_{s}, q$ are the same as Table 1

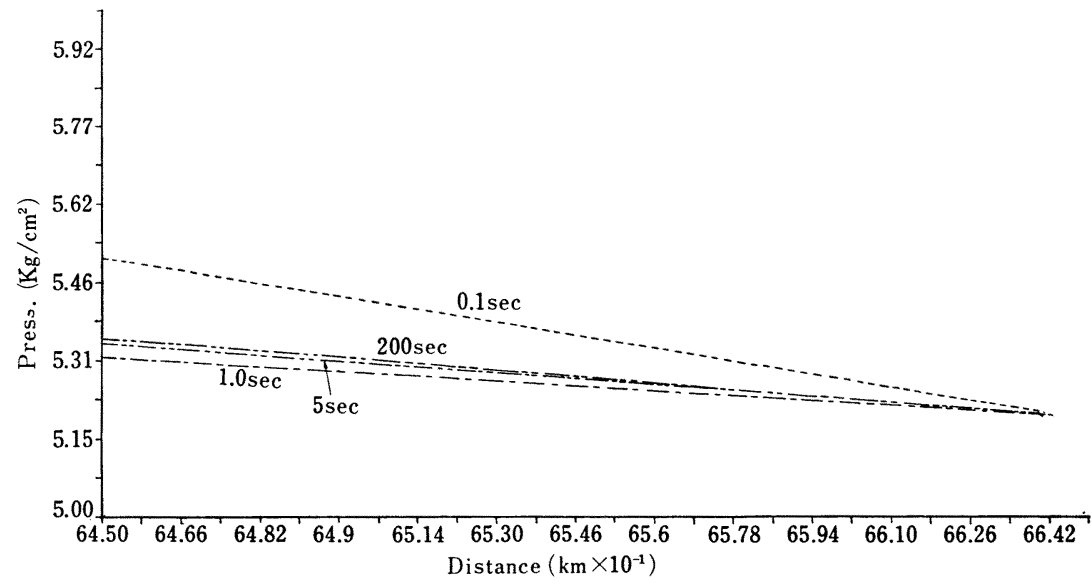

Fig. 3 The Pressure Transition around the Outlet Point (Disturbance Point) - Case Analysis A-18 - 


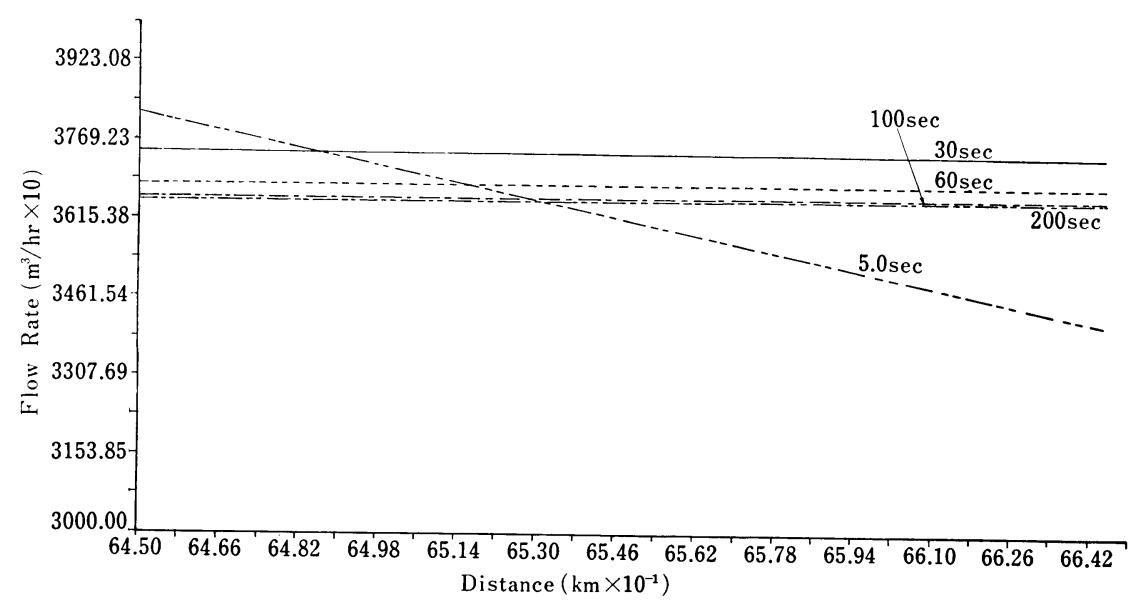

Fig. 4 The Flow Rate Transition around the Outlet Point (Disturbance Point) - Case Analysis A-18-

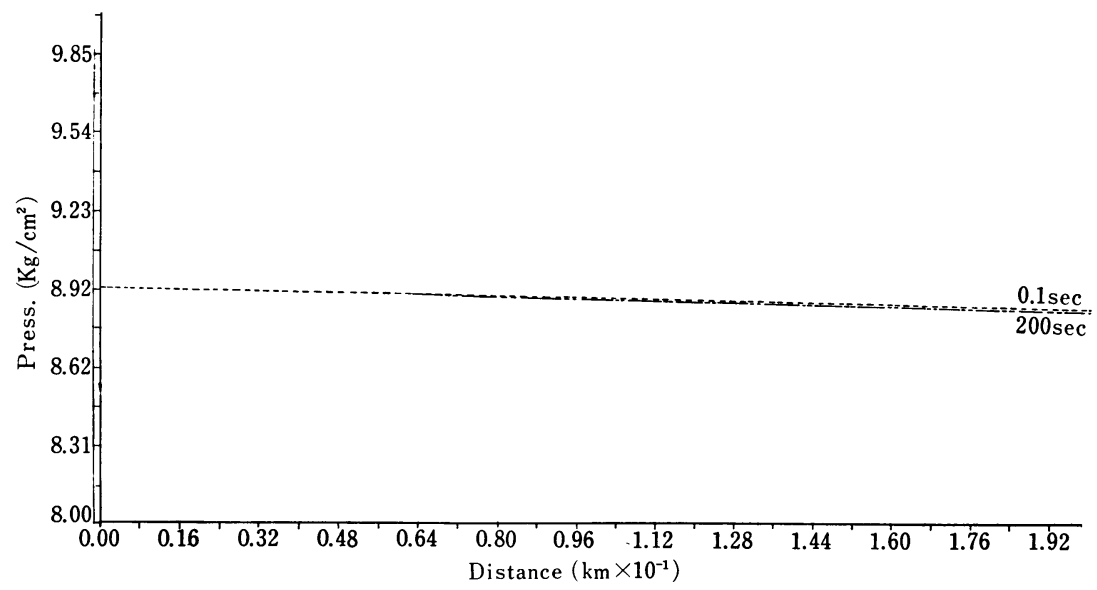

Fig. 5 The Pressure Transition around the Inlet Point -Case Analysis A-18-

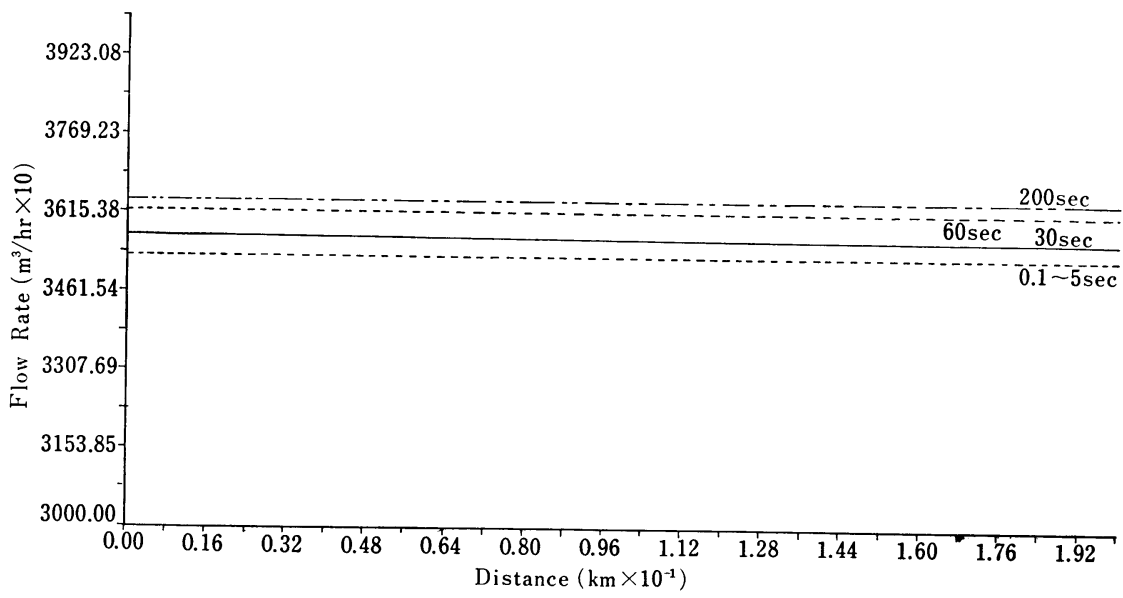

Fig. 6 The Flow Rate Transition around the Inlet Point - Case Analysis A-18-

(1) Initial conditions :

$Q: 35,100 \mathrm{~m}^{3} / \mathrm{hr}$

$P_{1}: 8.95 \mathrm{Kg} / \mathrm{cm}^{2}$

$P_{2}: 5.50 \mathrm{Kg} / \mathrm{cm}^{2}$

$\bar{T}: 29.35^{\circ} \mathrm{C}$

$$
\begin{array}{r}
Z_{0}: 0.98 \\
G: 0.65
\end{array}
$$

(2) Boundary conditions :

* Flow rate at both end sections; Fig. 9.

* Pressure at both end sections; 


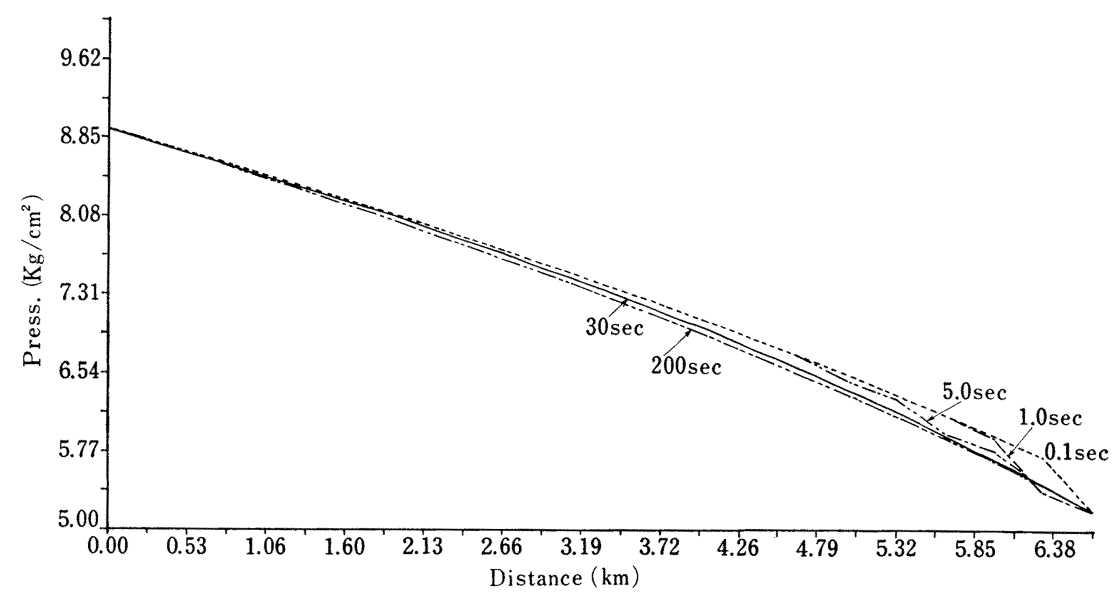

Fig. 7 The Pressure Transition along the Whole Length of Line - Case Analysis A-18

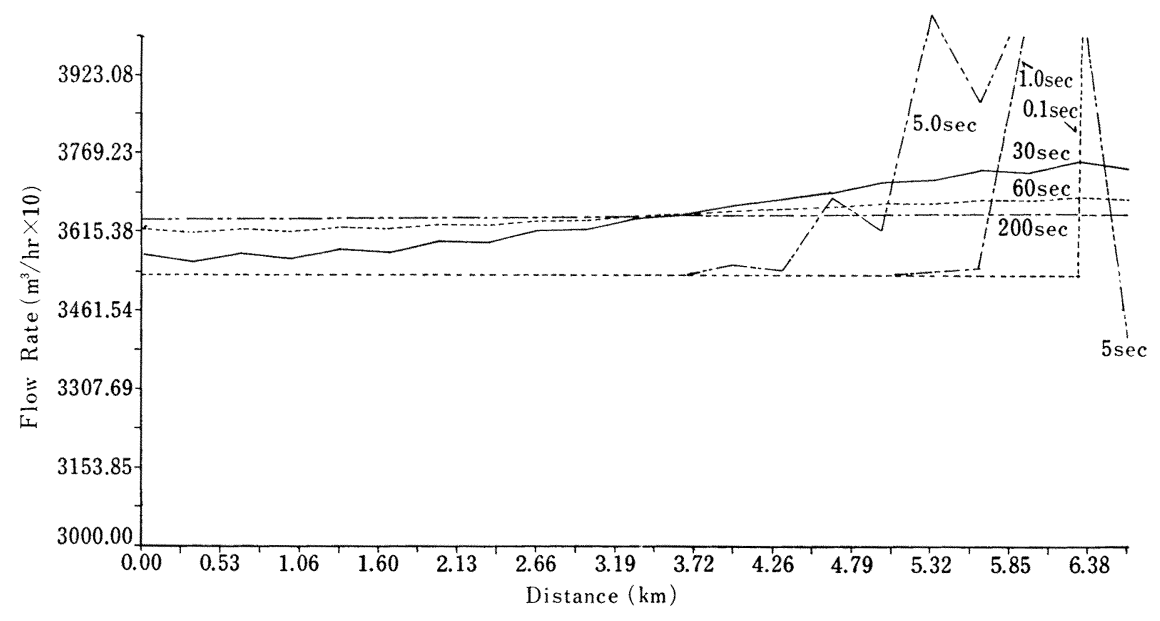

Fig. 8 The Flow Rate Transition along the Whole Length of Line - Case Analysis A-18-

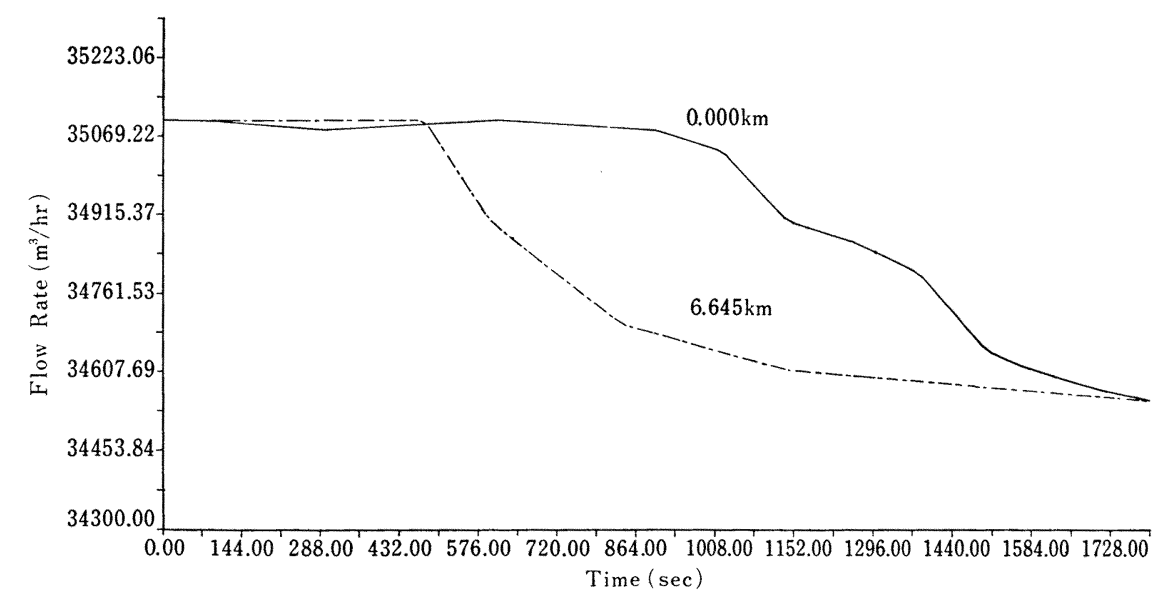

Fig. 9 The Flow Rate Transition at Both End Section in Actual and Simulation Case : Fixed Boundary Condition - Case Analysis B-

Calculated by method G, (the selected section was two meters from the end section)

(3) $\Delta t / \Delta x=15.0 \times 10^{-4} \mathrm{sec} / \mathrm{m}(\Delta x=L / 20 \Delta t=$ $0.5 \mathrm{sec})$

(4) $1 / v=75 \times 10^{-4} \mathrm{sec} / \mathrm{m}\left(Q=35,000 \mathrm{~m}^{3} / \mathrm{hr}\right)$
(5) $(4) \div(3)=5$

(6) $\varepsilon=1 \times 10^{-5}$

The results of simulation are shown in Fig. 10. The dotted line indicates the actual data and the other line is the simulation result. 


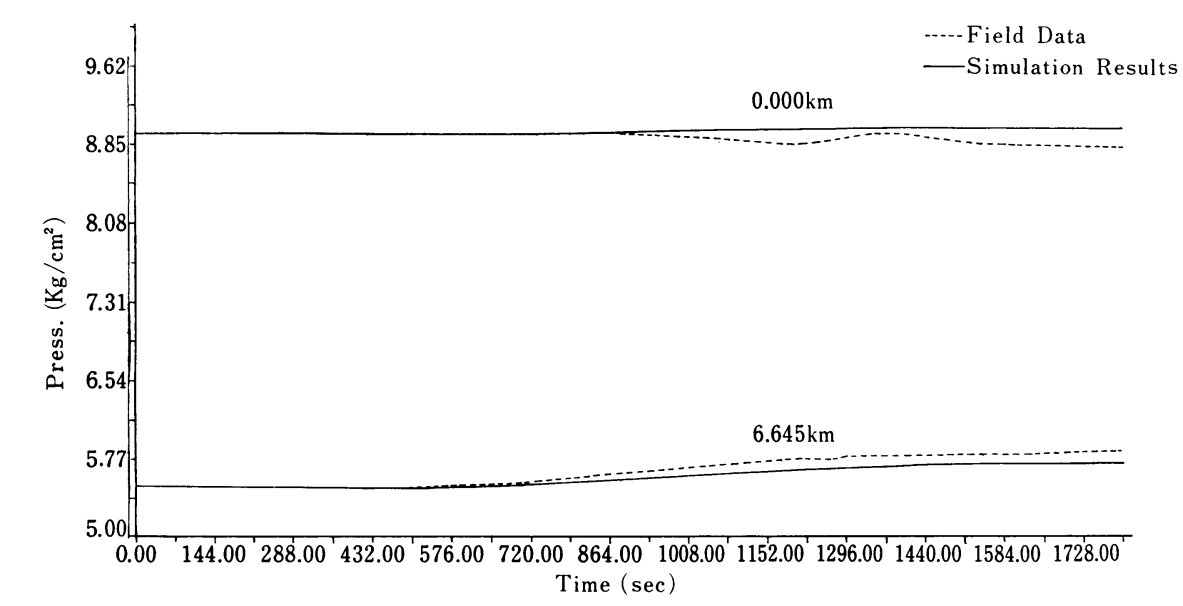

Fig. 10 The Pressure Transition at Both End Section of Actual Data and Simulation Results -Case Analysis B-

\section{Discussion}

\subsection{The Span ' $r$ '}

If there is not any suction part in the flow line, the pressure does not become minus at any point. However, in the calculation of Eq. (6); if the calculation span ' $r$ ' $(\Delta t / \Delta x)$ is large or the flow rate change between $x+\Delta x$ and $x-\Delta x$ is very large or the flow rate itself is large, the pressure $P(x, t+\Delta t)$ becomes minus. The cause of this large flow rate change is also a way of selecting ' $r$ ' in Eq. (6). Namely, if $\Delta t$ is selected very long, the flow rate $Q_{n}(x, t+\Delta t)$ is changed greatly. On the other hand, if $\Delta x$ is selected long, the second term and the third in brackets in Eq. (5) will be getting smaller. The flow rate change therefore will not become large. This means that a smaller span ' $r$ ' is better for selecting, and it is dependent on the flow rate which is velocity in the pipeline. From the results in Table 1 (column 4), it may be determined that the span should be selected smaller than the value of $1 / 2.37 v$. However, the simulation time may be long to obtain the required answer when the span ' $r$ ' selected is a small value. Therefore, it would be better to select a value for span ' $r$ ' in the range from $1 / 2.5 v$ to $1 / 5 v$.

\subsection{The Calculation Method of Boundary Condition}

It is understandable from Table 2, when the inside section, the outside section, and the selected section are of suitable distances, the results of methods $\mathrm{A}, \mathrm{B}$ and $\mathrm{G}$ are not so different. Therefore, method $\mathrm{C}$ is better for selection, because this method does not need the inside section, which requires considering divided length $(\Delta x)$, and the outside section requires no need to consider that length.

\subsection{Errors (Value of $\varepsilon$ )}

The simulator which uses 'Simultaneous Difference Equations' may lead to several errors. However, if there is no calculation, the error will, of course, not appear, and a lesser number of calculation steps will reduce the number of errors. Therefore, the procedure, which was described in section 5.3, was used. In the simulation case A-4, a trial calculation without the procedure given in section 5.3 was made.

Accumulation of errors appeared in 10 seconds, and after 80 seconds the flow rate value at the outlet point was showing an unrealistic value such as greater than $100,000 \mathrm{~m}^{3}$. In spite of that the flow rate may be calculated approximately 36,500 $\mathrm{m}^{3}$ in this case under steady state conditions. Therefore, we can determine that the simulation procedure in section 5.3 is very suitable and important for eliminating the errors.

The problem is what values of $\varepsilon$ should be selected. When $\varepsilon$ was selected as a large value, from Table 3, the following points were realized.

(1) the time when inlet flow rate is changed, $(t)$, is getting longer,

(2) the time when both flow rates become constant, $\left(T_{s}\right)$, gets shorter,

(3) the flow rate difference between inlet and outlet sections at $T_{s},(q)$, gets larger.

Namely, if the value of $\varepsilon$ selected is a large value, the result of simulation become coarse. The transmition by small disturbance, therefore, cannot strictly be simulated. However, if the value of $\varepsilon$ selected is very small, the error is accumulated and the computing time will be very long as has been described before. Therefore, it may be judged that the suitable $\varepsilon$ is $1 \times 10^{-5}$ by 
consideration of the results of Table 3 .

\subsection{The Selected Section}

The results are not so different in Table 4 . Therefore, it can be mentioned that the position of the selected section is not too important in the method C. However, if the computing time is considered, A-18 should be selected because of the values of $\Delta x$ and $\Delta t$

\subsection{Reliability of Simulator (Analysis B)}

The best method for checking the reliability of simulation is to compare the results, which are obtained by generating the same disturbance with these of the actual field pipeline. The data, therefore, were selected from the field, and the simulation was conducted. However, the conditions of the simulation case and these of the field case could not be the same. The differences were as follows : (1) The selected field pipeline has been sales line for three chemical factories. The flow rate to the biggest company was about $98 \%$, and the flow rate change to the other smaller companies was very small. Therefore, the assumption was made that the other two small companies were located at the same point as was company A, and their flow rates and pressures were constant. (2) The pipeline was under operation, so the control practice was constantly maintained by the operator, and there are separators at inlet point and outlet point which are connected directly to factories. This means that the pressure at both points was influenced not only by simple disturbance but also by the separator conditions and usage. (3) The starting condition assumed to be a steady state. From careful examination of Figs. 9 and 10, it was observed that the pressure at the outlet point had not reached a perfectly stable condition on the selected pipeline. This was still a small decrease even when the outlet flow rate had started to decrease, because of the small influence of the last disturbance of flow; however, it was neglected in the simulation case. (4) The pressure gauge and the flow rate recorder at both ends of the pipeline were different, so they might have individual, independent errors. However in the simulation case the difference was neglected.

Considering the above conditions, it may be recognized from Fig. 10 that the results of simulation tests do resemble the actual gas flow; thus, the simulations which are described in this paper are reliable.

\subsection{Result of Case Analysis A-18}

The flow rate disturbance around the pipeline was kept up for approximately five seconds, then it reached a steady-state condition with large oscillations after about a half to two minutes as shown in Fig. 8. This phenomenon was very great at the disturbed point. Against this flow rate phenomenon, the phenomenon of pressure disturbance had small oscillations around the disturbed point as shown in Figs. 7. Therefore, it may be determined that the pressure disturbance propagation is simpler, clearer, and easier to read than the flow rate. These features are noteworthy phenomena and also very convenient for automatic control of a pipeline by computer.

This phenomenon was applied to the computer control of the NAKAJO GAS FIELD. Namely, in the control loop, the flow rate, which is indicated by a flow counter, was not used, and the calculated flow rate obtained by using the pressure change value at the outlet point and the inlet point was used for controlling the flow rate. This method of control has been very successful ${ }^{1)}$.

\section{Conclusions}

(1) The simulation method, which applies to the Simultaneous-Difference-Equation (Eqs. (5) and (6)) as described in this paper, is a reliable method for researching an unsteady-state of gas flow in pipelines.

(2) In the simulator, the pressure values along the whole pipeline, $\left(P\left(x_{i}, t+\Delta t\right)\right)$ should be calculated at first and if the pressure values at three points $\left(x_{k}-\Delta x, x_{k}, x_{k} \times \Delta x\right)$ in the pipeline are changed by a very small amount $(\varepsilon)$, the flow rate $Q_{n}\left(x_{k}, t+\Delta t\right)$ should not be calculated by Eq. (5) and should be fixed at the same value as $Q\left(x_{k}, t\right)$. Only in the case when a bigger pressure change than the value $\varepsilon$ appears at one of these three points, Eq. (5) is used for correction.

(3) The suitable value of $\varepsilon$ described above is about $1 \times 10^{-5}$ considering the round off errors and computing time.

(4) The calculation span ' $r$ ' should be selected depending on the velocity in the pipeline and computing time. The range of suitable values of ' $r$ ' is from $1 / 2.5 v$ to $1 / 5 v$.

(5) It is not a serious problem that the selection of the inside section be a half-length of the general span $\Delta x$ from the end section. (method $\mathrm{A}$ ). However, method $\mathrm{C}$ is better than method A for selecting the selected section. 
(6) When method $\mathrm{G}$ is used, the selected section can be selected at any distance between 2 and 50 meters from the end section.

(7) It is recommended that the friction factor $\left(f_{m}\right)$ which is calculated from the field data under steady-state conditions, rather than some theoretical value will be used.

(8) The disturbance propagation on the pressure change (disturbance) seems clearer than that of flow rate and its oscillation is smaller.

\section{Acknowledgement}

The author would like to thank Prof. Shozo Tanaka (Tohoku Univ.) and Prof. Hiroshi Ishikawa (Akita. Univ.) for advice during the preparation of this paper. The author would also like to thank Nippon Mining Co., Ltd. for permission to publish this paper.

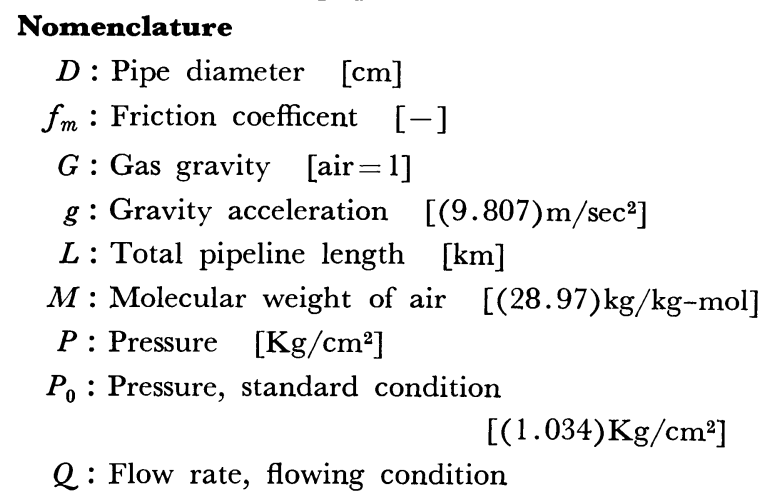
$\left[\mathrm{cm}^{3} / \mathrm{sec}, \mathrm{m}^{3} / \mathrm{hr}\right]$
$Q_{n}:$ Flow rate, standard condition $\left[\mathrm{cm}^{3} / \mathrm{sec}, \mathrm{m}^{3} / \mathrm{hr}\right]$

$R:$ Gas constant $[(847.8) \mathrm{Kg}-\mathrm{m} / \mathrm{kg}-\mathrm{mol} \cdot \mathrm{K}]$

$S:$ Cross section area $\left[\mathrm{cm}^{2}\right]$

$t:$ Time [sec]

$T:$ Temperature $[\mathrm{K}]$

$T_{0}$ : Temperature, standard condition $[(273.2) \mathrm{K}]$

$v:$ Velocity $[\mathrm{cm} / \mathrm{sec}]$

$x:$ Distance $[\mathrm{cm}, \mathrm{km}]$

$Z$ : Gas compressibility [-]

$Z_{0}$ : Gas compressibility, at $\cdot T_{0}, P_{0} \quad[-]$

$\rho:$ Density $\left[\mathrm{g} / \mathrm{cm}^{3}\right]$

(一): Average value [-]

\section{References}

1) Tanaka, T., "A systematic approach to computer production control in Nakajo Gas Field, Japan", 9th World Petroleum Congress, (1975).

2) Kaplan, M., "Analysing pipe line transients by method of characteristics", The Oil \& Gas Jour, Jan. (1968).

3) Sabersky, R. H. et al., "Fluid Flow", The Cacmillan Co., (1971).

4) Weymouth, T. R., "Problems in Natural Gas Engineering" ASME 34 (1912).

5) Katz, D. L. et al., "Handbook of Natural Gas Engineering" McGraw Hill Book Co., (1959).

6) Frick, T. C., Tylar, R. W., "Petroleum Production Handbook", McGraw Hill Book Co., (1962).

7) Selby, S. M., "Standard Mathematical Table", The Chemical Rubber Co., (1969).

8) Hughes, Gayland, "Basic Equation of Engineering Science" Schaun Publishing Co., (1960). 
要 旨

\title{
パイプラインにおけるガスの非定常流に関するシュミレーション
}

\author{
田中達 生*
}

定常的にガスが流れている一本のパイプラインに対し，一端 の圧力あるいは流量に外乱（昇圧・増量等）を与光た時, その 外乱の影響がどのようにパイプライン内に伝達するかを, シュ ミレーションにより考察した。すなわち, パイプラインにおけ る，ガスの非定常流動を運動の式 Eq. (1) および 連続の 式 Eq.（2）としてとら古，これを展開した後，フィールド・ユ ニットを入れて連立差分方程式 Eqs. (5)，（6）としてとら えた。これを用いて単一パイプライン系に対するユニット・シ ュミレーターをコンピューター内に作成し, 外乱発生後の流動 状況を諸ケースについて調査した。

シュミレーターの構成および使用したシュミレーション方法 は次の通りである。

（I）初期条件：外乱発生前の流動状態は定常流とするとい ら仮定より Eq. (10) を用いて求めた。なお Eq. (10) の摩擦 係数 $f_{m}$ は，モデルに使用した実パイプライン・データより求 めた。

（II）外乱の与方：問題を明解にするため，外乱はパイプ ラインのいずれかの端に一度与え, それを保持するものとし た。

（III）境界条件：Eqs.（5)，（6）を解くには4 個の境界条 件 $Q_{n}(0, t) P(0, t), Q_{n}(L, t), P(L, t)$ が要求される。こ の内 2 個は与えられた外乱数值および（I）で定めた初期值と して定め得るが，他の 2 個は Eqs. (5)，（6）の解として求 められるもので, 前もって定めることが出来ない。

そこで (Fig. 2 参照), (a)パイプライン両端（境界点）より $\Delta x / 2$ はなれた所に内点をもらけ，この内点と境界点に打ける ガス流動は瞬時に定常流となるという仮定を立て, Eqs. (5), (6) により $\Delta t$ 時間後の内点の圧力, 流量をもとめ, この数値 より Eqs.（8)，（9）を用いてその時刻における境界点の圧 力, あるいは流量を求める。(方法 $\mathrm{A}$ ) (b内点として $\Delta x / 4$ を 取り (a)同様な方法により境界值を求める。(方法 B) (C)パ プラインの系外 $\Delta x$ の所に架空点を定め, この点と境界点にお けるガス流動が瞬時に定常流となるという仮定を立て他は(a) と同様とする。ただし外乱時に打ける境界值のみは適当な点を 選択点として 用い方法 $\mathrm{A}$ を用いる。(方法 $\mathrm{G}$ ) の 3 方法を使用 した。

(N) シュミレーションの進め方 : 基本的には, Eqs. (5), （6）を用いて $\Delta t$ 時間後の各点における圧力, 流量を求めてい

*日本鉱業株式会社（105 東京都港区虎/門 2-10-1)
く方法であるが, 単純にこの方法をくり返すと, 式の係数中に あるまるめの誤差等が系内に伝播し, 長時間後の解析值は, か なり非理論的な数值を示す恐れがある。誤差の大きな伝播は

Fig. 1 より明らかなように，まず1 時刻先の流量にあらわ れ，次いで 2 時刻先の圧力にあらわれるといら系路をたどる。 そこで, ある地点 $x$ 㧊よびその前後 $x+\Delta x, x-\Delta x$ の 3 点の圧 力が前時刻と変わらなければ，その間の流量は変わらない点に 注目し，系を $\Delta t$ 進める際，まず Eq.（6）により系内の圧力 を計算し, 前記 3 点の圧力変化をみて, 変化量 $(\varepsilon)$ の多い時 のみ Eq. (5) を使用し, 少ない時は $Q_{n}(x, t+\Delta t)=Q_{n}(x, t)$ としてシュミレーションを進めることとした。

ケース・アナリシスは, とはどの位の数值が良いか, 境界値 の計算方法は $\mathrm{A} ， \mathrm{~B} ， \mathrm{C}$ のいずれが良いか，シュミレーション ステップ $\Delta t / \Delta x$ はどの位が最適か等, 最適シュミレーション 方法を見つけることを目的として，パイプラインの終点圧力に 外乱を与えて行い，次いで，このようにして作成されたシュミ レーターの信頼性を見ることを目的として，実パイプライン挙 動より得られた数值を用いてシュミレーションを行い, 両者の 比較を行った。

その結果（1）シュミレーションステップは，パイプライン 内の流速（v）により異なり，シュミレーション時間等を考兄 た時， $1 / 2.5 v \sim 1 / 5$ v が最適である。(Table 1 参照) (2) 境界值の求め方は, 方法 $\mathrm{C}$ が最適である。(Table 2 参照)

(3) 前記 $\varepsilon$ は, シュミレーション時間等も考えた時 $1 \times 10^{-5}$ が 最適である。(Table 3 参照) (4) 万方法 Cにおいて外乱時にお ける境界值を求める点は, それ程問題でないがュンピューター 操作時間を考慮すべきである。(Table 4 参照) の 4 点が判明 した。これら条件を用いた Table 4，A-18 のケースにつき シュミレーションを行った結果は Figs. 3〜8 の通りであり, 通常考兄られるパイプライン内の非定常流動を良くあらわして いた。

次に，このようにして作成されたシュミレーターの信頼性を 調査すべく，Fig. 9 に示した実パイプラインにおけるパイプ ライン両端の流量変化の数值を用いてシュミレーションを行っ た。結果は Fig. 10 に示す実線の通りである。これは点線で 示した実パイプラインに拈ける現実の圧力変化と非常に良くあ っており，本シュミレーション方法およびシュミレーターの信 頼性を立証した。

\section{Keywords}

Continuity equation, Kinetic equation, Pipeline, Simulation, Unsteady gas flow 